\title{
PENGARUH PARTISIPASI ANGGARAN DAN KEJELASAN SASARAN ANGGARAN TERHADAP KINERJA MANAJERIAL DENGAN KOMITMEN ORGANISASIONAL SEBAGAI VARIABEL MODERATING PADA PEMERINTAH KOTA BATU
}

\author{
Puji Handayati, Brilian Prastiti Andri Safitri \\ Universitas Negeri Malang \\ Email: Puji.handayati.fe@um.ac.id
}

\begin{abstract}
ABSTRAK
Penelitian ini bertujuan untuk mengetahui pengaruh partisipasi anggaran dan kejelasan anggaran terhadap kinerja manajerial dengan variabel moderasi komitmen organisasi. Penelitian ini menggunakan pendekatan kuantitatif dengan menggunakan jenis penelitian eksplanatori. Populasi yang digunakan adalah Organisasi Perangkat Daerah di Kota Batu. Sampel penelitian terdiri dari 100 pejabat pemerintah di tingkat manajer menengah di instansi pemerintah Kota Batu. Teknik pengambilan sampel adalah total sampling. Pengumpulan data menggunakan kuesioner. Teknik distribusi kuesioner dalam penelitian ini dilakukan dengan kuesioner yang dikelola secara pribadi. Analisis data dalam penelitian ini menggunakan analisis regresi linier sederhana dan Moderated Regression Analysis dengan SPSS 23. Berdasarkan hasil penelitian, ditemukan bahwa (1) partisipasi anggaran berpengaruh positif signifikan terhadap kinerja manajerial pemerintah, (2) komitmen organisasi memoderasi (memperkuat) pengaruh partisipasi anggaran pada kinerja manajerial pemerintah (3) tujuan anggaran kejelasan memiliki efek positif yang signifikan terhadap kinerja manajerial pemerintah, (4) komitmen organisasi memoderasi (memperkuat) efek kejelasan tujuan anggaran pada kinerja manajerial pemerintah.
\end{abstract}

Kata Kunci: partisipasi anggaran, kejelasan sasaran anggaran, komitmen organisasi, kinerja manajerial.

\section{PENDAHULUAN}

Fenomena yang terjadi saat ini pada Pemerintah Daerah Kota Batu yakni ditemukan bahwa kinerja manajerial belum dapat maksimal, hal ini terbukti dengan adanya temuan Audit BPK yang menyatakan bahwa pada tahun 2017 terdapat SILPA sejumlah 138 Milyar, membengkaknya SILPA ini diakibatkan karena adanya penurunan realisasi belanja daerah dan kurang optimalnya pelaksanaan program-program pembangunan daerah. Kemudian fenomena lainnya pada pemerintah Kota Batu terhitung pada Bulan Oktober 2018 masih ada enam OPD yang penyerapan anggarannya belum maksimal yakni belum mencapai 50\%, keenam OPD tersebut adalah Dinas Perumahan, Kawasan Permukiman dan Pertanahan Kota Batu yang hanya menyerap 13,8 persen, Dinas 
Penanggulangan Kebakaran yang hanya melakukan penyerapan 35,6 persen, Dinas Kesehatan hanya menyerap 39,2 persen, Dinas PUPR penyerapannya hanya sebesar 44 persen, DP3AP2KB masih 47 persen dan Bappeda penyerapannya hanya sebesar 46,5 persen (Anonimous, 2018). Hal tersebut berarti bahwa terdapat program pemerintah yang belum berjalan secara maksimal.

New Public Management memberikan perubahan manajemen sektor publik yang cukup drastis dari sistem manajemen tradisional yang terkesan kaku, birokratis, dan hierarkis menjadi model manajemen sektor publik yang fleksibel dan lebih mengakomodasi kebutuhan masyarakat dan pasar (Denhardt \& Denhardt dalam Winengan, 2018:67). Perubahan tersebut telah mengubah peran pemerintah terutama dalam hal hubungan antara pemerintah dengan masyarakat serta masyarakat dengan pasar. Pengelolaan anggaran yang efektif dan effisien menjadi kunci keberhasilan dari penerapan New Public Management. Berdasarkan teori tersebut di atas maka pemerintah daerah wajib mengelola keuangan secara mandiri, profesional serta efektif dan efisien. Hal tersebut berakibat pada fungsi dan peran yang harus dimainkan para pejabat di daerah (Rohman, 2012). Para pejabat yang melakukan fungsi perencanaaan serta pengendalian anggaran merupakan seseorang yang bertanggung jawab atas organisasi atau unit yang dipimpinnya dalam Organisasi Perangkat Daerah yang selanjutnya disebut dengan OPD.

Anggaran merupakan rencana keuangan untuk masa depan yang mengidentifikasikan tujuan tindakan yang dibutuhkan untuk mencapai tujuan sebuah perusahaan (Hansen dan Mowen, 2013:423). Anggaran pada organisasi sektor swasta mengalokasikan dana untuk mendapatkan keuntungan yang maksimal (profit oriented) sedangkan pada sektor publik mengalokasikan dananya untuk memberikan pelayanan yang maksimal terhadap masyarakat. Kinerja manajerial satuan kerja perangkat daerah juga merupakan gambaran mengenai tingkat pencapaian sasaran anggaran atau tujuan sebagai penjabaran dari visi, misi, dan strategi pemerintah daerah yang mengindikasikan tingkat keberhasilan atau kegagalan pelaksanaaan kegiatan-kegiatan sesuai dengan tugas pokok dan fungsi aparatur pemerintah (Putra, 2013).

Adanya pendekatan partisipasi merupakan kerja sama dan interaksi antara manajer puncak dan manajer tingkat bawah. Dengan demikian, penyusunan anggaran menjadi kompleks karena akan berdampak pada perilaku dan sikap fungsional dan disfungsional anggota organisasi. Hal ini senada dengan Garrison (2013:385) yang mengemukakan bahwa partisipasi dalam penganggaran dalam organisasi mempunyai pengaruh besar terhadap target yang dianggarkan. Jadi, partisipasi penganggaran merupakan suatu proses dimana kinerja individu akan dievaluasi, diberikan penghargaan, atau hukuman berdasarkan dari tingkat pencapaian target anggarannya yang mana nantinya juga akan berpengaruh terhadap kinerja yang dihasilkan.

Selain partisipasi anggaran, faktor lain yang dapat mempengaruhi kinerja manajerial adalah kejelasan sasaran anggaran. Menurut Kenis dalam Putra (2013), kejelasan sasaran anggaran merupakan sejauh mana tujuan anggaran ditetapkan secara jelas dan spesifik 
dengan tujuan agar anggaran tersebut dapat dimengerti oleh orang yang bertanggungjawab atas pencapaian sasaran anggaran tersebut.

Penelitian mengenai hubungan partisipasi anggaran dan kejelasan sasaran anggaran terhadap kinerja manajerial telah banyak dilakukan oleh peneliti-peneliti sebelumnya. Namun dalam hasilnya masih menunjukkan pengaruh yang berbeda-beda. Misalnya, dalam penelitian Kamilah (2013), Hidayat (2014) dan Kewo (2014) mengungkapkan bahwa di Indonesia, hubungan antara variabel partisipasi anggaran dengan kinerja manajerial mempunyai hubungan positif secara signifikan. Sedangkan hasil tersebut bertentangan dengan penelitian yang dilakukan oleh Risdiana (2017) yang menunjukkan bahwa tidak ada pengaruh antara partisipasi anggaran terhadap kinerja manajerial.

Hubungan antara variabel kejelasan sasaran anggaran terhadap kinerja manajerial pada penelitian terdahulu yang dilakukan Darma (2004) Hidayat (2014), Kewo (2014) dan Risdiana (2018) yang menunjukkan bahwa kejelasan sasaran anggaran berpengaruh signifikan positif terhadap kinerja pemerintah daerah. Selain itu, Putra (2013) mengatakan bahwa pelaksanaan anggaran memberikan reaksi positif dan secara relatif hal ini dikarenakan kejelasan sasaran anggaran sangat berpengaruh kuat dalam meningkatkan kinerja menejerial. Akan tetapi, pada penelitian yang dilakukan oleh Harsanti (2010) yang meneliti tentang faktor-faktor yang mempengaruhi akuntabilitas kinerja instansi pemerintah daerah Kabupaten Kudus yang salah satu faktornya adalah kejelasan sasaran anggaran menunjukkan hasil yang berbeda yakni kejelasan sasaran anggaran berpengaruh negatif tidak signifikan terhadap akuntabilitas kinerja pemerintah daerah.

Komitmen organisasional sendiri merupakan suatu hasrat yang mendorong individu untuk melaksanakan kegiatan demi kesuksesan organisasi (Wiener dalam Sumarno, 2005). Dari penjelasan diatas, peneliti menyimpulkan bahwa komitmen sangat dibutuhkan oleh seluruh anggota dari suatu organisasi. Manajer yang memiliki komitmen organisasional yang tinggi akan akan termotivasi untuk meningkatkan usahanya dalam memperoleh informasi yang mendukung dalam pengambilan keputusan dalam penyusunan anggaran sehingga dapat memperoleh informasi yang relevan yang dapat meningkatkan kinerja manajerialnya. Hal tersebut juga berlaku pada organisasi di dalam pemerintahan seperti yang telah dilakukan dalam Pemerintahan Daerah Kota Batu. Kota Batu sebagai Kota Wisata yang cukup berkembang dan di dalamnya memiliki struktur organisasi yang cukup besar sangat memerlukan adanya komitmen dalam kinerja setiap karyawannya untuk menjalankan misi-misi agar visi yang ditetapkan dapat tercapai. Penelitian oleh Apsari dan Sujana (2013) menyimpulkan bahwa komitmen organisasi mampu memoderasi (memperkuat) hubungan antara budgetary goal characteristic tehadap kinerja manajerial. Semakin tinggi komitmen organisasional yang dirasakan individu dalam suatu kelompok maka semakin tinggi pula perasaan atau hasrat untuk melaksakan tugas dengan baik yang akan berpengaruh terhadap kinerjanya.

\section{TINJAUAN PUSTAKA}




\subsection{Teori New Public Management (NPM)}

Secara umum Konsep NPM berangkat dari gagasan Christopher Hood pada tahun 1991 sebagai awal mula paradigma alternative. New Public Management tidak selalu dipahami sama oleh semua orang, bagi sementara orang, NPM adalah suatu system manajemen desentral dengan perangkat-perangkat manajemen baru seperti controlling, benchmarking dan lean management, bagi yang lain, NPM dipahami sebagai privatisasi sejauh mungkin atas aktivitas pemerintah (Wibowo, 2014). Penggunaan paradigma New Public Management (NPM) tersebut menimbulkan beberapa konsekuensi bagi pemerintah diantaranya adalah tuntutan untuk melakukan efisiensi, pemangkasan biaya, dan kompetensi tender. Strategi itu memberikan perubahan manajemen sektor publik yang cukup drastis dari sistem manajemen tradisional yang terkesan kaku, birokratis, dan hierarkis menjadi model manajemen sektor publik yang fleksibel dan lebih mengakomodasi pasar. Perubahan tersebut bukan sekedar perubahan kecil dan sederhana.

NPM sebagai paradigma baru dalam manajemen publik yang dapat menimbulkan beberapa hal yang menjadi tuntutan dari pemerintah diantaranya tuntutan untuk melakukan efisiensi, pemangkasan biaya, dan kompetensi tender. Dengan adanya partisipasi anggaran maka diharapkan kinerja pelayanan publik khususnya dalam hal kinerja manajerialnya mampu memberikan control hasil/keluaran yang lebih efisien karena pegawai diberikan keleluasaan untuk berpartisipasi dalam menentukan anggaran sesuai yang benar-benar dibutuhkan oleh organisasinya sehingga mampu meningkatkan kinerja manajerialnya.

\subsection{Anggaran}

Indra Bastian (2010:191), menyatakan bahwa berdasarkan National Committee on Governmental Accounting (NCGA) yang saat ini telah diubah menjadi Governmental Accounting Standards Board (GASB), pengertian dari anggaran (budget) adalah "...rencana operasi keuangan yang mencakup estimasi pengeluaran yang diusulkan, dan sumber pendapatan yang diharapkan untuk membiayainya dalam periode waktu tertentu".

Nordiawan (2012:70), anggaran merupakan sebuah rencana financial yang menyatakan rencana-rencana organisasi untuk melayani masyarakat atau aktivitas lain dapat mengembangkan kapasitas organisasi dalam pelayanan, estimasi besarnya biaya yang harus dikeluarkan dalam merealisasikan rencana tersebut, perkiraan sumbersumber mana saja yang akan menghasilkan pemasukan serta seberapa besar pemasukan tersebut.

Dari pengertian-pengertian di atas, dapat diperoleh makna bahwa anggaran berisi rencana-rencana kerja, rencana keuangan yang berhubungan dengan aktivitas organisasi dalam jangka waktu tertentu. Paparan di atas dapat pula dipahami bahwa anggaran merupakan sebuah proses yang dilakukan oleh organisasi sektor publik untuk dijadikan pedoman atas rencana-rencana organisasi untuk melayani masyarakat atau aktivitas lain dapat mengembangkan kapasitas organisasi dalam pelayanan, meliputi rencana 
pendapatan, belanja, transfer, dan pembiayaan yang diukur dalam satuan rupiah yang disusun menurut klasifikasi tertentu secara sistematis untuk suatu periode.

\subsection{Pendekatan dalam Penyusunan Anggaran}

Dalam proses penyusunan anggaran, terdapat beberapa pendekatan yang lazim digunakan diantaranya, pendekatan dari atas ke bawah (top down approach), dari bawah ke atas (bottom up approach) serta pendekatan lain merupakan anggaran partisipatif (Siregar et al, 2013:117).

Penyusunan anggaran dari atas ke bawah (top down approach), manajemen tingkat puncak menetapkan anggaran yang harus dilaksanakan oleh manajemen pusat pertanggung jawaban tingkat bawah/pegawai. Pada proses penyusunan anggaran dari bawah ke atas (bottom up approach) pegawai melalui manajer pusat pertanggung jawaban mengajukan usulan kepada manajemen tingkat atas/puncak untuk ditelaah dan ditetapkan. Dalam hal ini manajemen tingkat bawah ikut menyampaikan spirasinya. Sedangkan dalam anggaran partisipatif yang merupakan gabungan dari kedua pendekatan tersebut yang memungkinkan keterlibatan interaksi yang efektif dari manajemen puncak dan manajemen pusat pertanggungjawaban atau manajemen tingkat bawah dalam proses penyusunan anggaran.

\subsection{Partisipasi Anggaran}

Hansen dan Mowen (2013:223) mendefinisikan partisipasi anggaran merupakan "pendekatan penganggaran yang memungkinkan para manajer dari seluruh tingkatan akan bertanggung jawab atas kinerja anggaran, untuk berpartisipasi dalam pengembangan anggaran, partisipasi anggaran serta mengkomunikasikan rasa tanggung jawab kepada para manajer tingkat bawah dan mendorong kreativitas".

Berdasarkan penjelasan diatas, maka peneliti dapat menyimpulkan bahwa partisipasi anggaran merupakan bentuk partisipasi penuh oleh seluruh manajer dari semua tingkatan atas tanggungjawab sesuai dengan jabatan mengenai proses kinerja anggaran dari penyusunan anggaran, dimana aliran data anggaran, pengembangan anggaran dan mengkomunikasikan anggaran kepada para manajer tingkat bawah. Hal tersebut dilakukan untuk menjaga keuangan organisai agar data yang dihasilkan benar.

\subsection{Kejelasan Sasaran Anggaran}

Kejelasan sasaran anggaran merupakan sejauh mana tujuan anggaran ditetapkan secara jelas dan spesifik dengan tujuan agar anggaran tersebut dapat dimengerti oleh orang bertanggung jawab atas pencapain sasaran anggaran tersebut (Kennis dalam Putra 2013). Salah satu penyebab tidak efektif dan efisiennya anggaran dikaren akan ketidakjelasan sasaran anggaran yang mengakibatkan aparat pemerintah daerah mengalami kesulitan dalam penyusunan target - target anggaran (Chici, 2013).

Berdasarkan penjelasan diatas, maka peneliti dapat menyimpulkan bahwa dengan adanya sasaran anggaran yang jelas, aparat pelaksana anggaran juga akan terbantu 
dalam perealisasian anggarannya, secara tidak langsung ini akan mempengaruhi terhadap kinerja aparat termasuk kinerja manajerialnya. Untuk mencapai hal tersebut, maka ada beberapa hal yang perlu diperhatikan dalam suatu penganggaran diantaranya adanya sasaran yang spesifik dan menantang namun tetap dapat dicapai oleh para pegawainya.

\subsection{Komitmen Organisasional}

Komitmen organisasi adalah suatu konstruk psikologis yang merupakan karakteristik hubungan anggota organisasi dengan organisasinya, dan memiliki implikasi terhadap keputusan individu untuk melanjutkan keanggotaannya dalam berorganisasi. (Darmawan, 2013:169). Lain halnya yang dikatakan oleh Robbins and Judges dalam Subagja (2017:30) bahwa komitmen organisasi didefinisikan sebagai kekuatan yang bersifat relative dari individu dalam mengidentifikasikan keterlibatan dirinya kedalam bagian organisasi, yang dicirikan oleh penerimaan nilai dan tujuan organisasi, kesediaan berusaha demi organisasi dan keinginan mempertahankan keanggotaan dalam organisasi.

Berdasarkan penjelasan diatas maka peneliti dapat menyimpulkan bahwa komitmen organisasi merupakan suatu tanggungjawab setiap indivisd atas keputusan individu untuk melanjutkan keanggotaannya dalam berorganisasi. Maka dari itu setiap individu yang menjadi anggota dalam suatu organisasi harus memiliki komitmen organisasi yang akan diberikan kepada organisasinya.

\subsection{Kinerja Manajerial}

Kinerja merupakan suatu hasil kerja yang dicapai seseorang dalam melaksanakan tugas - tugas yang dibebankan kepadanya yang didasarkan atas kecakapan, pengalaman, kesungguhan serta waktu. Kinerja manajerial adalah suatu hasil kerja yang dicapai seseorang dalam kegiatan - kegiatan manajerial. Kinerja manajerial dalam sebuah organisasi merupakan suatu hal yang sangat penting, karena dengan kinerja manajerial yang baik dapat menciptakan keunggulan daya saing suatu organisasi.

Menurut Mahmudi (2013:9) kinerja manajerial adalah sejauh mana anggota organisasi publik melakukan pengelolaan organisasi secara efektif dan efisien sebagai bentuk pertanggungjawaban (performance accountability). Akuntabilitas manajerial berkaitan dengan proses organisasi dimana seluruh kegiatan organisasi harus dapat dipertanggungjawabkan dengan kata lain tidak terjadi inefisiensi dan ketidakefektifan.

Berdasarkan penjelasan diatas, maka peneliti dapat menyimpulkan bahwa kinerja manajerial menunjukkan kemampuan dan prestasi seorang manajer dalam menjalankan organisasi untuk mewujudkan tujuan yang mengarah kepada ketercapaian pelayanan publik. Kepentingan kinerja manajerial dibutuhkan untuk menilai seberapa jauh lembaga/organisasi dapat menerapkan visi, misinya agar pelayanan publik dapat terwujud. Salah satu bentuk konsistensinya adalah perlu dilakukannya bentuk aktivitas yaitu melakukan penjaringan aspirasi masyarakat dan adanya kejelasan dalam partisipasi penyusunan anggaran yang terpadu sehingga dapat tercapai suatu sistem yang dapat 
mencegah atau meminimalisasi terjadinya kesalahan dalam mewujudkan good governance.

\section{METODE PENELITIAN}

Jenis penelitian yang dilakukan adalah explanatory research (penelitian penjelasan) dengan menggunakan metode penelitian survei. Pendekatan dalam penelitian ini adalah pendekatan kuantitatif. Untuk pemahaman rancangan penelitian ini dapat dilihat pada gambar 3.1 sebagai berikut:

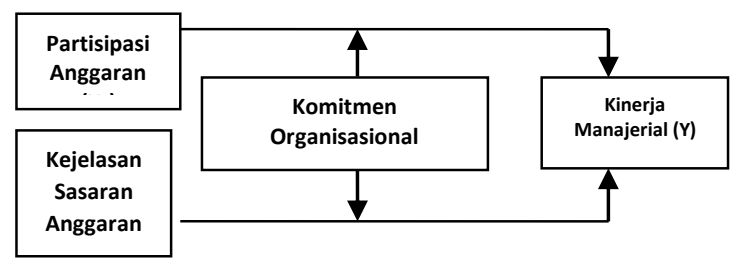

Gambar 1: Rancangan Penelitian

Populasi dalam penelitian ini adalah seluruh manajer atau pimpinan unit kerja atau seluruh pegawai di pemerintah daerah kota Batu. Teknik sampling yang digunakan oleh penulis adalah total sampling. Jadi jumlah sampel yang digunakan dalam penelitian ini

sama dengan jumlah populasi yaitu 145 responden.

Dalam penelitian ini, pengujian hipotesis dilakukan dengan analisis regresi yang dimoderasi (Multiple Regression Analysis /MRA).

Pengaruh variabel independen dan dependen akan diperkuat dengan komitmen organisasional sebagai variabel moderasi. Berikut model regresi yang akan digunakan dalam penelitian ini:

$$
\begin{aligned}
& \mathrm{KM}=\alpha+\beta_{1} \mathrm{X}_{1}+\mathrm{e} \\
& \mathrm{KM}=\alpha+\beta_{1} \mathrm{X}_{1}+\beta_{2} \mathrm{Z}+\beta_{3} \mathrm{X}_{1} * \mathrm{Z}+\mathrm{e} \\
& \mathrm{KM}=\alpha+\beta_{1} \mathrm{X}_{2}+\mathrm{e} \\
& \mathrm{KM}=\alpha+\beta_{1} \mathrm{X}_{2}+\beta_{2} \mathrm{Z}+\beta_{3} \mathrm{X}_{2} * \mathrm{Z}+\mathrm{e}
\end{aligned}
$$

Keterangan:

$$
\begin{array}{ll}
\mathrm{KM} & =\text { Kinerja Manajerial } \\
\alpha & =\text { Konstanta } \\
\mathrm{X}_{1} & =\text { Partisipasi Anggaran } \\
\mathrm{X}_{2} & =\text { Kejelasan Sasaran Anggaran }
\end{array}
$$


$\mathrm{Z}=$ Komitmen Organisasional

$\beta_{1}-\beta_{5}=$ Koefisien regresi

$\beta_{3} \mathrm{X}_{1} * \mathrm{Z}=$ Interaksi antara partisipasi anggaran dengan komitmen organisasional

$\beta_{3} \mathrm{X}_{2} * \mathrm{Z}=$ Interaksi antara kejelasan sasaran anggaran dengan komitmen organisasional

e $=$ error

\section{HASIL DAN PEMBAHASAN}

\section{Partisipasi Anggaran}

Tabel 4.8 Analisis Statistik Deskriptif Partisipasi Anggaran

\begin{tabular}{lccccccc}
\hline Pernyataan & N & Mean & Mode & $\begin{array}{c}\text { Std. } \\
\text { Deviation }\end{array}$ & Min & Max & Sum \\
\hline PA 1 & 100 & 4.04 & 4 & 0.764 & 2 & 5 & 404 \\
PA 2 & 100 & 4.35 & 5 & 0.716 & 3 & 5 & 435 \\
PA 3 & 100 & 4.41 & 5 & 0.753 & 3 & 5 & 441 \\
PA 4 & 100 & 4.03 & 4 & 0.745 & 1 & 5 & 403 \\
PA 5 & 100 & 4.05 & 4 & 0.845 & 2 & 5 & 405 \\
PA 6 & 100 & 4.02 & 4 & 0.887 & 1 & 5 & 402 \\
\hline SUM PA & 100 & 24.90 & 26 & 3.797 & 13 & 30 & 2490
\end{tabular}

Variabel partisipasi anggaran dalam penelitian ini diukur dengan mengggunakan enam indikator dan setiap indikator memiliki masing-masing satu item pernyataan dalam kuisioner. Setiap item pernyataan memiliki 5 alternatif jawaban sehingga secara keseluruhan nilai harapan tertinggi sebesar 30, sedangkan nilai harapan terendah adalah 6 pada variabel ini. Berdasarakan pengolahan data pada tabel 4.8 dapat diketahui bahwa dalam penelitian ini diperoleh nilai tertinggi sebesar 30 dan nilai terendah adalah 13 dengan standar deviasi sebesar 3,797, sedangkan nilai rata-rata sebesar 24,90.

Kejelasan Sasaran Anggaran 
Tabel 4.10 Analisis Statistik Deskriptif Kejelasan Sasaran Anggaran

\begin{tabular}{lccccccc}
\hline Pernyataan & N & Mean & Mode & $\begin{array}{c}\text { Std. } \\
\text { Deviation }\end{array}$ & Min & Max & Sum \\
\hline KSA 1 & 100 & 3.99 & 4 & 0.659 & 2 & 5 & 399 \\
KSA 2 & 100 & 3.74 & 4 & 0.705 & 2 & 5 & 374 \\
KSA 3 & 100 & 4.06 & 4 & 0.600 & 1 & 5 & 406 \\
KSA 4 & 100 & 4.13 & 4 & 0.747 & 2 & 5 & 413 \\
KSA 5 & 100 & 4.04 & 4 & 0.875 & 1 & 5 & 404 \\
KSA 6 & 100 & 3.96 & 4 & 0.710 & 2 & 5 & 396 \\
KSA 7 & 100 & 4.03 & 4 & 0.745 & 1 & 5 & 403 \\
\hline SUM KSA & 100 & 27.95 & 31 & 3.942 & 15 & 33 & 2795 \\
\hline
\end{tabular}

Variabel kejelasan dalam penelitian ini diukur dengan mengggunakan tujuh indikator dan setiap indikator memiliki masing-masing satu item pernyataan dalam kuisioner. Setiap item pernyataan memiliki 5 alternatif jawaban sehingga secara keseluruhan nilai harapan tertinggi sebesar 35, sedangkan nilai harapan terendah adalah 7 pada variabel ini. Berdasarakan pengolahan data pada tabel 4.10 dapat diketahui bahwa dalam penelitian ini diperoleh nilai tertinggi sebesar 33 dan nilai terendah adalah 15 dengan standar deviasi sebesar 3,942, sedangkan nilai rata-rata sebesar 27,95.

\section{Komitmen Organisasional}

Tabel 4.12 Analisis Statistik Deskriptif Komitmen Organisasional

\begin{tabular}{lccccccc}
\hline Pernyataan & N & Mean & Mode & $\begin{array}{c}\text { Std. } \\
\text { Deviation }\end{array}$ & Min & Max & Sum \\
\hline KO 1 & 100 & 4.05 & 4 & 0.744 & 2 & 5 & 405 \\
KO 2 & 100 & 4.34 & 5 & 0.755 & 2 & 5 & 434 \\
KO 3 & 100 & 4.40 & 5 & 0.752 & 3 & 5 & 440 \\
KO 4 & 100 & 4.06 & 4 & 0.600 & 1 & 5 & 406 \\
KO 5 & 100 & 4.13 & 4 & 0.747 & 2 & 5 & 413 \\
KO 6 & 100 & 4.04 & 4 & 0.875 & 1 & 5 & 404 \\
KO 7 & 100 & 3.96 & 4 & 0.710 & 2 & 5 & 396 \\
KO 8 & 100 & 3.85 & 4 & 0.783 & 2 & 5 & 385 \\
KO 9 & 100 & 4.08 & 4 & 0.774 & 2 & 5 & 408 \\
KO 10 & 100 & 4.10 & 4 & 0.732 & 2 & 5 & 410 \\
KO 11 & 100 & 4.04 & 4 & 0.724 & 2 & 5 & 404 \\
KO 12 & 100 & 4.06 & 4 & 0.776 & 2 & 5 & 406 \\
\hline SUM KO & 100 & 49.11 & 52 & 6.737 & 28 & 57 & 4911 \\
\hline
\end{tabular}


Variabel komitmen organisasional dalam penelitian ini diukur dengan mengggunakan tiga indikator dan pada indikator pertama memiliki lima item pernyataan, pda indikator kedua memiliki 4 item pernyataan dan pada indikator ketiga memiliki 3 item pernyataan dalam kuisioner. Setiap item pernyataan memiliki 5 alternatif jawaban sehingga secara keseluruhan nilai harapan tertinggi sebesar 60, sedangkan nilai harapan terendah adalah 12 pada variabel ini. Berdasarakan pengolahan data pada tabel 4.12 dapat diketahui bahwa dalam penelitian ini diperoleh nilai tertinggi sebesar 57 dan nilai terendah adalah 28 dengan standar deviasi sebesar 6,737, sedangkan nilai rata-rata sebesar 49,11 .

\section{Kinerja Manajerial}

Tabel 4.14 Analisis Statistik Deskriptif Kinerja Manajerial

\begin{tabular}{lccccccc}
\hline Pernyataan & N & Mean & Mode & $\begin{array}{c}\text { Std. } \\
\text { Deviation }\end{array}$ & Min & Max & Sum \\
\hline KM 1 & 100 & 4.08 & 4 & 0.907 & 2 & 5 & 408 \\
KM 2 & 100 & 4.32 & 5 & 0.750 & 3 & 5 & 432 \\
KM 3 & 100 & 4.27 & 5 & 0.777 & 3 & 5 & 427 \\
KM 4 & 100 & 4.03 & 4 & 0.745 & 1 & 5 & 403 \\
KM 5 & 100 & 4.00 & 4 & 0.865 & 2 & 5 & 400 \\
KM 6 & 100 & 4.04 & 4 & 0.724 & 2 & 5 & 404 \\
KM 7 & 100 & 4.06 & 4 & 0.600 & 1 & 5 & 406 \\
KM 8 & 100 & 3.96 & 4 & 0.710 & 2 & 5 & 396 \\
KM 9 & 100 & 4.03 & 4 & 0.745 & 1 & 5 & 403 \\
\hline SUM KM & 100 & 36.79 & 38 & 5.353 & 28 & 44 & 3679 \\
\hline
\end{tabular}

Variabel kinerja manajerial dalam penelitian ini diukur dengan mengggunakan sembilan indikator dan setiap indikator memiliki masing-masing satu item pernyataan dalam kuisioner. Setiap item pernyataan memiliki 5 alternatif jawaban sehingga secara keseluruhan nilai harapan tertinggi sebesar 45, sedangkan nilai harapan terendah adalah 9 pada variabel ini. Berdasarakan pengolahan data pada tabel 4.14 dapat diketahui bahwa dalam penelitian ini diperoleh nilai tertinggi sebesar 44 dan nilai terendah adalah 28 dengan standar deviasi sebesar 5,353, sedangkan nilai rata-rata sebesar 36,79. 


\section{Hasil Regresi Linier Sederhana Variabel Partisipasi Anggaran}

\section{Coefficients $^{\mathrm{a}}$}

\begin{tabular}{|c|c|c|c|c|c|c|}
\hline \multirow{2}{*}{\multicolumn{2}{|c|}{ Model }} & \multicolumn{3}{|c|}{$\begin{array}{cc} & \text { Standardi } \\
& \text { zed } \\
\text { Unstandardized } & \text { Coefficien } \\
\text { Coefficients } & \text { ts }\end{array}$} & \multirow[b]{2}{*}{$\mathrm{t}$} & \multirow[b]{2}{*}{ Sig. } \\
\hline & & B & Std. Error & Beta & & \\
\hline \multirow[t]{2}{*}{1} & (Constant) & .278 & .192 & & 1.447 & .151 \\
\hline & $\begin{array}{l}\text { X1_Partisipasi_Anggar } \\
\text { an }\end{array}$ & .931 & .046 & .899 & 20.294 & .000 \\
\hline
\end{tabular}

a. Dependent Variable: Y_Kinerja_Manajerial Sumber : Output SPSS yang diolah Penulis (2019)

Berdasarkan hasil regresi linier sederhana pada tabel diatas, maka persamaan regresi adalah sebagai berikut :

$$
\begin{aligned}
& \mathrm{KM}=\alpha+\beta_{1} \mathrm{X}_{1}+\mathrm{e} \\
& \mathrm{KM}=0,278+0,931 \mathrm{X}_{1}+\mathrm{e}
\end{aligned}
$$

Hasil uji t dilihat dari tabel 4.19, dari tabel tersebut dapat diketahui bahwa partisipasi anggaran $\left(\mathrm{X}_{1}\right)$ memiliki $\mathrm{t}_{\text {hitung }} 20,294>\mathrm{t}_{\text {tabel }} 1.984$ dengan nilai siginikansi sebesar $0.000<0.05$ sehingga dapat diambil kesimpulan bahwa $\mathrm{H}_{01}$ ditolak dan $\mathrm{H}_{1}$ diterima, yang berarti pada penelitian ini variabel partisipasi anggaran berpengaruh positif signifikan terhadap kinerja manajerial.

\section{Hasil MRA untuk Variabel Moderasi 1}

\section{Coefficients $^{\mathrm{a}}$}

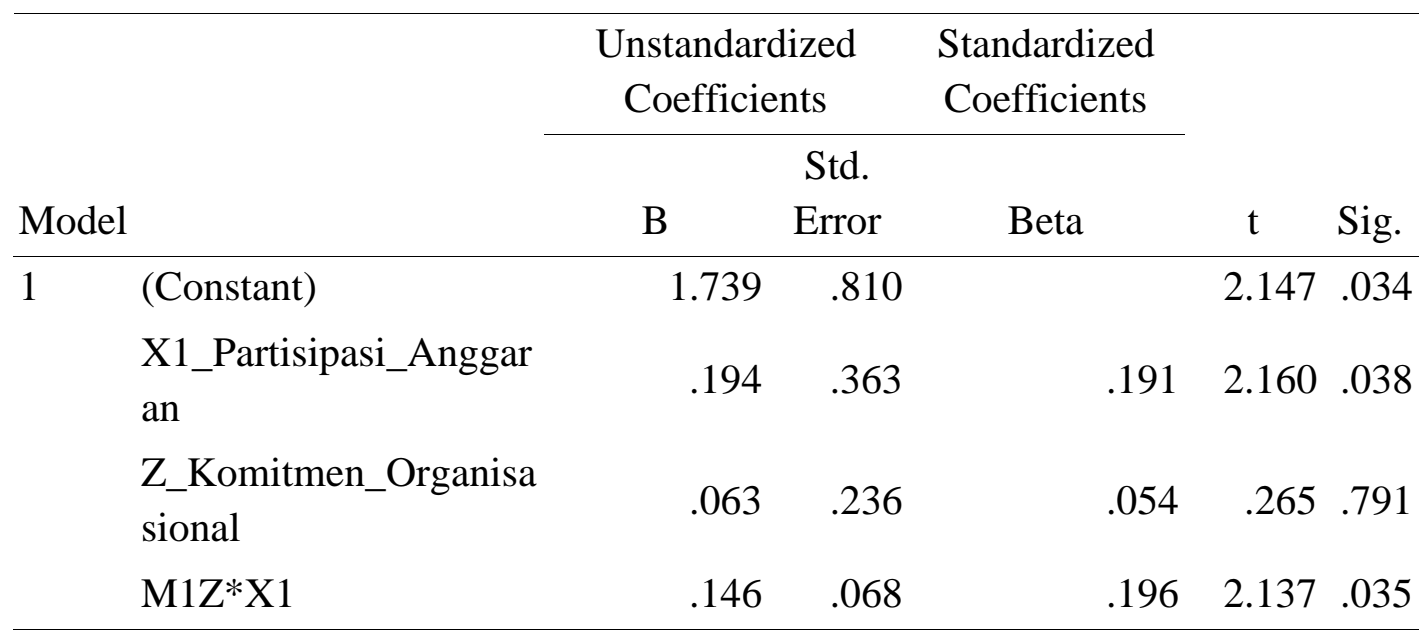

a. Dependent Variable: Y_Kinerja_Managerial 


\section{Sumber : Output SPSS yang diolah Penulis}

(2019)

Berdasarkan hasil regresi moderasi pada tabel diatas, maka persamaan regresi adalah sebagai berikut :

$$
\begin{aligned}
& \mathrm{KM}=\alpha+\beta_{1} \mathrm{X}_{1}+\beta_{2} Z+\beta_{3} \mathrm{X}_{1} * Z+\mathrm{e} \\
& \mathrm{KM}=1,739+0,194 \mathrm{X}_{1}+0,063 Z+0,146 \mathrm{X}_{1} Z+\mathrm{e}
\end{aligned}
$$

Hasil uji t dilihat dari tabel 4.21, dari tabel tersebut dapat diketahui bahwa partisipasi anggaran $\left(\mathrm{X}_{1}\right)$ memiliki $\mathrm{t}_{\text {hitung }} 2,160>\mathrm{t}_{\text {tabel }}$ 1,984 dengan nilai siginikansi sebesar $0,038<0,05$, komitmen organisasional (Z) memiliki $t_{\text {hitung }} 0,265<t_{\text {tabel }} 1,984$ dengan nilai siginikansi sebesar $0,791>0,05$, dan variabel moderasi $\left(\mathrm{X}_{1} * \mathrm{Z}\right)$ memiliki $\mathrm{t}_{\text {hitung }} 2,137>\mathrm{t}_{\text {tabel }} 1,984$ dengan nilai siginikansi sebesar $0,035<0,05$ sehingga dapat diambil kesimpulan bahwa $\mathrm{H}_{02}$ ditolak dan $\mathrm{H}_{2}$ diterima, yang berarti pada penelitian ini variabel komitmen organisasi memoderasi pengaruh partisipasi anggaran terhadap kinerja manajerial. Berdasarkan uraian tersebut juga dapat diketahui bahwa jenis moderasi dalam penelitian ini adalah moderasi mutlak (pure moderator) karena nilai $\beta_{2}$ tidak signifikan dan nilai $\beta_{3}$ signifikan

\section{Hasil Regresi Linier Sederhana Variabel Kejelasan Sasaran Anggaran Coefficients $^{\mathrm{a}}$}

\begin{tabular}{llllllll}
\hline & & \multicolumn{5}{c}{ Standardi } \\
zed \\
\end{tabular}

a. Dependent Variable: Y_Kinerja_Manajerial

Sumber : Output SPSS yang diolah Penulis (2019)

Berdasarkan hasil regresi linier sederhana pada tabel diatas, maka persamaan regresi adalah sebagai berikut :

$$
\begin{aligned}
& \mathrm{KM}=\alpha+\beta_{1} \mathrm{X}_{2}+\mathrm{e} \\
& \mathrm{KM}=0,024+1,011 \mathrm{X}_{2}+\mathrm{e}
\end{aligned}
$$


Hasil uji t dilihat dari tabel 4.23, dari tabel tersebut dapat diketahui bahwa kejelasan sasaran anggaran $\left(\mathrm{X}_{2}\right)$ memiliki $\mathrm{t}_{\text {hitung }} 21,134>\mathrm{t}_{\text {tabel }}$ 1,984 dengan nilai siginikansi sebesar $0,000<0,05$ sehingga dapat diambil kesimpulan bahwa $\mathrm{H}_{03}$ ditolak dan $\mathrm{H}_{3}$ diterima, yang berarti pada penelitian ini variabel kejelasan sasaran anggaran berpengaruh positif signifikan terhadap kinerja manajerial.

\section{Hasil MRA untuk Variabel Moderasi 2}

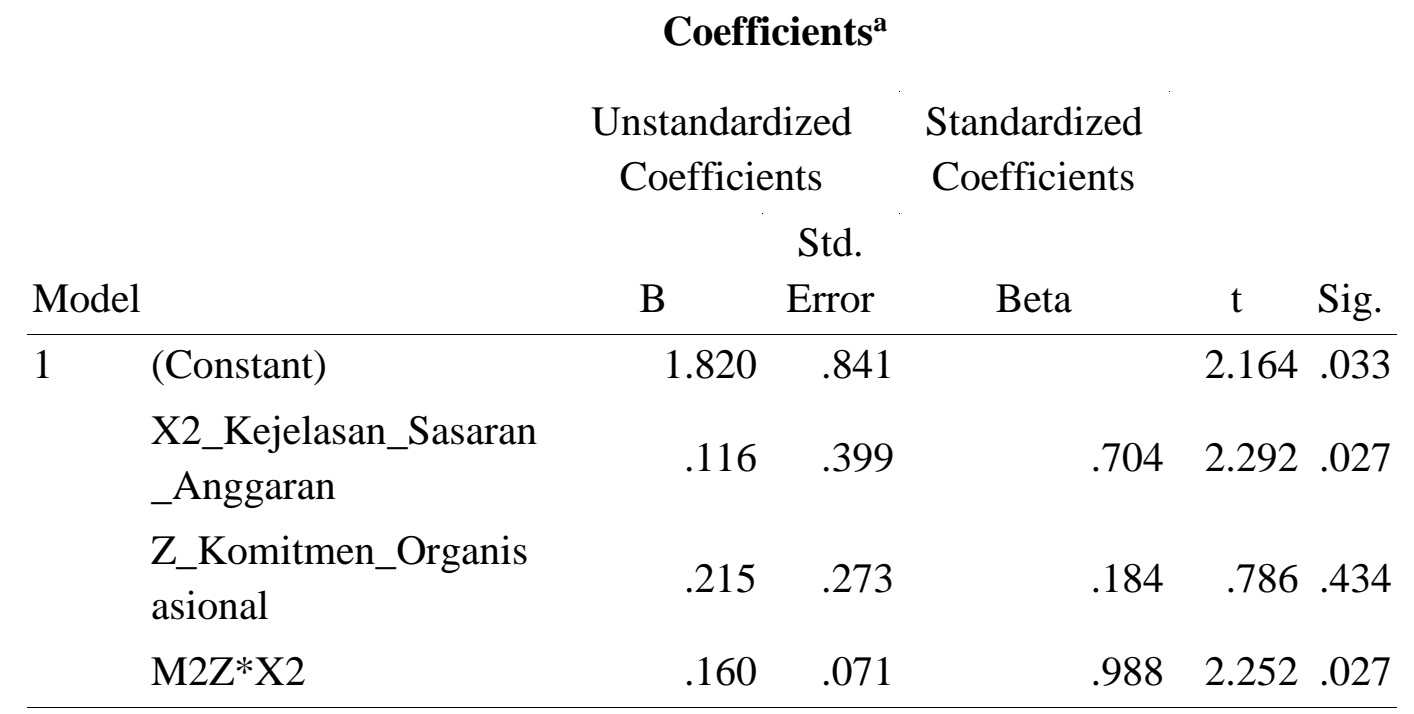

a. Dependent Variable: Y_Kinerja_Managerial

Sumber : Output SPSS yang diolah Penulis (2019)

Berdasarkan hasil regresi moderasi pada tabel diatas, maka persamaan regresi adalah sebagai berikut :

$$
\begin{aligned}
& \mathrm{KM}=\alpha+\beta_{1} \mathrm{X}_{2}+\beta_{2} Z+\beta_{3} \mathrm{X}_{2} * \mathrm{Z}+\mathrm{e} \\
& \mathrm{KM}=1,820+0,116 \mathrm{X}_{2}+0,215 \mathrm{Z}+0,160 \mathrm{X}_{2} * \mathrm{Z}+\mathrm{e}
\end{aligned}
$$

Hasil uji t dilihat dari tabel 4.25, dari tabel tersebut dapat diketahui bahwa kejelasan sasaran anggaran $\left(X_{2}\right)$ memiliki thitung 2,292 $>t_{\text {tabel }}$ 1,984 dengan nilai siginikansi sebesar $0,027<0,05$, komitmen organisasional $(\mathrm{Z})$ memiliki $t_{\text {hitung }} 0,786<\mathrm{t}_{\text {tabel }} 1,984$ dengan nilai siginikansi sebesar $0,434>0,05$, dan variabel moderasi $\left(\mathrm{X}_{1} * \mathrm{Z}\right)$ memiliki $\mathrm{t}_{\text {hitung }} 2,252>$ $\mathrm{t}_{\text {tabel }}$ 1,984 dengan nilai siginikansi sebesar $0,027<0,05$ sehingga dapat diambil kesimpulan bahwa $\mathrm{H}_{04}$ ditolak dan $\mathrm{H}_{4}$ diterima, yang berarti pada penelitian ini variabel komitmen organisasi memoderasi pengaruh kejelasan sasaran anggaran terhadap kinerja manajerial. Berdasarkan uraian tersebut juga dapat diketahui bahwa jenis moderasi dalam penelitian ini adalah moderasi mutlak (pure moderator) karena nilai $\beta_{2}$ tidak signifikan dan nilai $\beta_{3}$ signifikan. 


\section{Hasil Pembahasan}

\section{Pengaruh Partisipasi Anggaran Terhadap Kinerja Manajerial Pemerintah Daerah Kota Batu}

Dalam penelitian ini, hipotesis $\left(\mathrm{H}_{1}\right)$ yang diajukan adalah bahwa partisipasi anggaran berpengaruh positif terhadap kinerja manajerial. Berdasarkan uji hipotesis yang telah dilakukan memperlihatkan bahwa partisipasi anggaran berpengaruh positif signifikan terhadap kinerja manajerial di Pemerintah Daerah Kota Batu. Berarti dapat disimpulkan bahwa hipotesis $\left(\mathrm{H}_{1}\right)$ diterima. Dengan kata lain, hasil penelitian menunjukkan semakin tinggi tingkat partsipasi anggaran seorang manajer maka akan semakin tinggi pula kinerja manajerial yang dihasilkan.

Hasil penelitian ini sesuai dengan oleh hasil penelitian yang dilakukan oleh Kewo (2014), Hidayat (2014) dan Kamilah dkk (2013) dari hasil penelitian yang dilakukan menunjukkan bahwa partisipasi anggaran memiliki pengaruh positif terhadap kinerja manajerial, dimana pada penelitian sebelumnya juga dilakukan pada Pemerintah Daerah kecuali yang dilakukan oleh Kamilah dkk yang melakukan penelitian pada salah satu rumah sakit di Pekanbaru. Penelitian ini dilakukan pada Pemerintah Daerah Kota Batu dengan mengambil sampel berupa pegawai pemerintah daerah. Dengan demikian, dapat disimpulkan bahwa partisipasi anggaran pada organisasi sektor publik terutama pada Pemerintahan Kota/ Kabupaten berpengaruh dalam peningkatan kinerja manajerialnya.

Sedangkan hasil penelitian ini tidak konsisten dengan penelitian Risdiana (2018) yang menyatakan bahwa partisipasi anggaran tidak berpengaruh pada kinerja mananjerial. Penelitian ini dilakukan di Pemerintah Kabupaten Purworejo dimana partisipasi penyusunan anggaran pemerintah daerah dalam pembuatan tujuan anggaran menurun, maka kinerja aparat pemerintah daerahpun juga akan menurun. Selain itu adanya penyusunan program yang mendukung kinerja kurang optimal pelaksanaannya karena sebagian besar di dukung progam kerja harian sehingga tidak terfokus pada yang lain, hal ini sesuai dengan LKjIP Kabupaten Purworejo.

\section{Komitmen Organisasi Memoderasi Hubungan Antara Partisipasi Anggaran Terhadap Kinerja Manajerial Pemerintah}

Dalam penelitian ini, hipotesis $\left(\mathrm{H}_{2}\right)$ yang diajukan adalah bahwa komitmen organisasi memperkuat pengaruh partisipasi anggaran terhadap kinerja manajerial. Berdasarkan uji hipotesis yang telah dilakukan memperlihatkan bahwa komitmen organisasi memperkuat pengaruh partisipasi anggaran terhadap kinerja manajerial di Pemerintah Daerah Kota Batu. Berarti dapat disimpulkan bahwa hipotesis $\left(\mathrm{H}_{2}\right)$ diterima. Dengan kata lain, hasil penelitian menunjukkan semakin tinggi tingkat komitmen organisasi seorang manajer maka semakin tinggi pula pengaruh partisipasi anggaran terhadap kinerja manajerial yang dihasilkan.

Hasil penelitian ini sesuai dengan yang telah dilakukan oleh Kamilah dkk (2013), dan Apsari (2014) yang melakukan penelitian mengenai pengaruh komitmen organisasi 
sebagai variabel moderasi terhadap hubungan antara partisipasi anggaran terhadap kinerja manajerial dengan analisis yang sama dengan penelitian ini yaitu Moderated Regression Analysis (MRA). Hasil pada masing-masing penelitian tersebut menyatakan bahwa komitmen organisasi sebagai variabel moderasi berpengaruh positif signifikan terhadap kinnerja manajerial, dengan kata lain komitmen organisasi memperkuat hubungan partisipasi anggaran terhadap kinerja manajerial.

Sedangkan hasil penelitian ini tidak konsisten dengan penelitian Biduri (2011) yang dalam penelitiannya membuktikan bahwa komitmen organisasi tidak mampu menjadi variabel moderasi. Penelitian ini dilakukan di Pemerintah Kabupaten Lamongan dimana kurangnya komitmen manajerial terhadap organisasi dimana dia bekerja, kegiatan kegiatan berfokus pada kualitas dan pelayanan publik, sehingga tanpa partsisipasi dan komitmen organisasipun para manajer tetap bekerja.

\section{Pengaruh Kejelasan Sasaran Anggaran Terhadap Kinerja Manajerial Pemerintah Daerah Kota Batu}

Dalam penelitian ini, hipotesis $\left(\mathrm{H}_{3}\right)$ yang diajukan adalah bahwa kejelasan sasaran anggaran berpengaruh positif terhadap kinerja manajerial. Berdasarkan uji hipotesis yang telah dilakukan memperlihatkan bahwa kejelasan sasaran anggaran berpengaruh positif signifikan terhadap kinerja manajerial di Pemerintah Daerah Kota Batu. Berarti dapat disimpulkan bahwa hipotesis $\left(\mathrm{H}_{3}\right)$ diterima. Dengan kata lain, hasil penelitian menunjukkan semakin tinggi tingkat kejelasan sasaran anggaran yang dimengerti oleh seorang manajer maka akan semakin tinggi pula kinerja manajerial yang dihasilkan.

Hasil penelitian ini sesuai dengan oleh hasil penelitian yang dilakukan oleh peneliti Darma (2004), Putra (2013), Kewo (2014), Hidayat (2014) dan Risdiana (2018) dari hasil penelitian yang dilakukan oleh peneliti sebelumnya ini menunjukkan bahwa kejelasan sasaran anggaran berpengaruh positif signifikan terhadap kinerja manajerial. Pada penelitian sebelumnya juga dilakukan pada Pemerintah Daerah yang ada di Indonesia. Dengan demikian, dapat disimpulkan bahwa kejelasan sasaran anggaran pada organisasi sektor publik terutama pada Pemerintahan Kota/ Kabupaten berpengaruh dalam peningkatan kinerja manajerialnya.

Sedangkan hasil penelitian ini tidak konsisten dengan penelitian Harsanti (2010) dimana pada penelitian ini menemukan hasil bahwa kejelasan sasaran anggaran berpengaruh negatif tidak signifikan terhadap akuntabilitas kinerja pemerintah daerah.

\section{Komitmen Organisasi Dapat Memoderasi Hubungan Antara Kejelasan Sasaran Anggaran Terhadap Kinerja Manajerial Pemerintah}

Dalam penelitian ini, hipotesis $\left(\mathrm{H}_{4}\right)$ yang diajukan adalah bahwa komitmen organisasi memperkuat pengaruh partisipasi anggaran terhadap kinerja manajerial. 
Berdasarkan uji hipotesis yang telah dilakukan memperlihatkan bahwa komitmen organisasi memperkuat pengaruh partisipasi anggaran terhadap kinerja manajerial di Pemerintah Daerah Kota Batu. Berarti dapat disimpulkan bahwa hipotesis $\left(\mathrm{H}_{4}\right)$ diterima. Dengan kata lain, hasil penelitian menunjukkan semakin tinggi tingkat komitmen organisasi seorang manajer maka semakin tinggi pula pengaruh kejelasan sasaran anggaran terhadap kinerja manajerial yang dihasilkan.

Hasil penelitian ini sejalan dengan yang telah dilakukan oleh Ni Made Santi Apsari dan I Ketut Sujana yang melakukan penelitian mengenai pengaruh komitmen organisasi sebagai variabel moderasi terhadap hubungan antara kejelasan sasaran anggaran terhadap kinerja manajerial dengan analisis yang sama dengan penelitian ini yaitu Moderated Regression Analysis (MRA). Hasil dari penelitian tersebut menyatakan bahwa komitmen organisasi sebagai variabel moderasi berpengaruh positif signifikan terhadap kinnerja manajerial, dengan kata lain komitmen organisasi memperkuat hubungan kejelasan sasaran anggaran terhadap kinerja manajerial.

Sedangkan hasil penelitian ini tidak konsisten dengan penelitian yang dilakukan oleh Darma (2004) yang menyatakan bahwa variabel komitmen organisasi tidak dapat berperan sebagai pemoderasi pada hubungan antara kejelasan sasaran anggaran terhadap kinerja manajerial pada kabupaten dan kota se-provinsi DIY.

\section{KESIMPULAN DAN SARAN}

\section{Kesimpulan}

1. Partisipasi anggaran berpengaruh positif terhadap kinerja manajerial Pemerintah Daerah Kota Batu.

2. Komitmen organisasi mampu memoderasi (pure moderator)/ memperuat hubungan antara partisipasi anggaran terhadap kinerja manajerial Pemerintah Daerah Kota Batu.

3. Kejelasan sasaran anggaran berpengaruh positif terhadap kinerja manajerial Pemerintah Daerah Kota Batu.

4. Komitmen organisasi memoderasi (pure moderator)/ memperkuat hubungan antara kejelasan sasaran anggaran terhadap kinerja manajerial Pemerintah Daerah Kota Batu.

\section{Keterbatasan}

1. Pada penelitian ini menggunakan metode pengumpulan data dengan kuisioner dan pada saat pengisian kuisioner oleh responden, peneliti tidak mengawasi secara langsung sehingga jawaban responden bisa jadi tidak sesuai dengan keadaaan yang sebenarnya.

2. Pada penelitian ini kuisioner disebarkan secara langsung pada responden dan secara tidak langsung melalui perantara, sehingga bisa jadi kuisioner tidak tersampaikan pada responden atau bisa jadi pula orang lain yang mengisi kuisoner. 


\section{Saran}

Diharapkan bagi Pemerintah Daerah Kota Batu untuk meningkatkan partisipasi anggaran oleh seluruh manajernya terutama pada mengenai pengaruh manajer terhadap anggaran akhir/final dan lebih memperhatikan mengenai pendapat/usulan oleh manajer, meningkatkan kejelasan sasaran anggaran oleh seluruh manajer serta meningkatkan pemahaman bagaimana kinerja manajer diukur, serta meningkatkan komitmen organisasinya terutama pada keingin anmanajer untuk melibatkan diri dalam upaya mencapai tujuan organisasi.

Untuk penelitian selanjutnya diharapkan dapat mempertimbangkan penggunaan variabel-variabel lain yang dimungkinkan untuk mempengaruhi variabel kinerja manajerial seperti gaya kepemimpinan, budaya organisasi, informasi akuntansi dan sebagainya. serta mengguunakan metode analisis yang berbeda sehingga dapat mengembangkan hasil dari penelitian ini. Atau juga dapat menggunakan metode wawancara untuk memperoleh data, sehingga data lebih sesuai dengan keadaan yang sebenarnya.

\section{DAFTAR PUSTAKA}


Apsari, I Ketut Sujana, Ni Made Santi. 2013. Pengaruh Budgetary Goal Characteristics Terhadap Kinerja Manajerial Dengan Motivasi Dan Komitmen Organisasi Sebagai Variabel Moderating. E-Jurnal Akuntansi. Vol. 3 No. 1

Bastian, Indra. 2010. Akuntansi Sektor Publik: Suatu Pengantar. Jakarta: Erlangga.

Chici, Handayani. 2013. Pengaruh Partisipasi Dalam Penyusunan Anggaran dan Kejelasan Sasaran Anggaran Terhadap Kinerja Manajerial SKPD dengan Desentralisasi Sebagai Variabel Moderating, Studi Empiris Pada SKPD Pemerintah Daerah Kota Padang. Fakultas Ekonomi Universitas Negeri Padang.

Darmawan, D. 2013. Prinsip - prinsip Perilaku Organisasi. Surabaya: Pena Semesta. Hal: 169

Garrison, Ray H., Nooren, Eric W. \& Brewer, Peter C. 2013. Akuntansi Manajerial. Jakarta: Salemba Empat.

Hansen, Don.R dan Maryanne M. Mowen. 2013. Akuntansi Manajerial. Volume dua. Edisi Kedelapan. Jakarta: Salemba Empat.

Harsanti, Ponny, Sudaryati, Dwi dan Hilmia, Nora. 2010. Faktor-faktor yang Mempengaruhi Akuntanbilitas Kinerja Instansi Pemerintah Daerah Kabupaten Kudus. Sosial dan Budaya. ISSN 1979-6889.

Hidayat, Taufik. 2015. Pengaruh Kejelasan Sasaran Anggaran dan Locus of Control Terhadap Kinerja Mannajerial. Akuntabilitas: Vol VII No. 2, Agustus 2015.

Kewo, Cecilia Lelly. 2014. The Effect of Participative Budgeting, Budget Goal Clarity and Internal Control Implementation On Managerial Performance. Research Journal of Finance and Accounting, Vol.5, No. 12. Accounting Doctoral program Faculty of Economic and Business. Padjadjaran University-Indonesia.

Mahmudi. 2013. Manajemen Kinerja Sektor Publik. Sekolah Tinggi Ilmu Manajemen YKPN, Yogyakarta.

Nordiawan, Deddi dan Ayuningtyas Hertianti. 2012. Akuntansi Sektor Publik. Jakarta: Salemba Empat.

Putra, D. (2013). Pengaruh Akuntabilitas Publik dan Kejelasan Sasaran Anggaran terhadap Kinerja Manajerial Satuan Kerja Perangkat Daerah (SKPD) Kota Padang. Fakultas Ekonomi Universitas Negeri Padang.

Rohman. A. 2012. Pengaruh Peran Manajerial Pengelola Keuangan Daerah Dan Fungsi Pemeriksaan Intern Terhadap Kinerja Pemerintah Daerah. Jurnal MAKSI, Vol 7, No. 2, pp 206-220. 
Risdiana, Purwita. 2018. Pengaruh Partisipasi Penyusunan Anggaran, Kejelasan Sasaran Anggaran, Dan Budaya Organisasi Terhadap Kinerja Pemerintah Daerah Kabupaten Purworejo (Studi Empiris pada Dinas dan Badan Satuan Kerja Perangkat Daerah Kabupaten Purworejo). Jurnal Bisnis Strategi. Vol 10 No 2. Universitas Muhammadiyah Surakarta.

Siregar, Baldric., Suripto,, Bambang., Dody, Hapsoro., Widodo Lo, Eko. \& Biyanto, Frasto. 2013. Akuntansi Manajemen. Jakarta: Salemba Empat.

Subagja, Rochmat. 2017. Pengaruh Komitmen Dan Budaya Organisasi Terhadap Kinerja Karyawan Di CV. Wira Utama Garment Manufacture Cibabat Cimahi Jawa Barat. Skripsi diterbitkan. Fakultas Ekonomi dan Bisnis Unpas Bandung.Ha: 33-34.

Sumarno, J. 2005. Pengaruh Komitmen Organisasi dan Gaya Kepemimpinan terhadap Hubungan antara Partisipasi Penyusunan Anggaran dan Kinerja Manajerial. Jurnal Bisnis Strategi. Vol 14 No 2.

Wibowo, Sopan Aji. 2014. Teori New Publik Manajemen. (online), (https://www.academia.edu/9014200/teori_new_publik_manejemen), diakses 25 November 2018.

Winengan. 2018. Menakar Penerapan New Public Management dalam Birokrasi Indonesia. JIAP Vol. 4, No. 1, pp 66-74. FIA UB. 